\title{
Strategic Profiles of the International Dimension in Universities in Uganda
}

\author{
Ronald Bisaso and Florence Nakamanya
}

\begin{abstract}
This article is based on a study that explored the nature of and variations in strategic profiles of internationalisation in universities in Uganda. Six universities, comprising of three public and three private chartered universities with different histories and philosophies were selected for the study. Profiles of the international dimension were ascertained through a review and analysis of national and institutional strategic plans and reports. The findings highlight six profiles of internationalisation, namely, vision and mission, shared/core value, student enrolment, staff and student exchange, partnerships and collaborations, and the management structure. It is imperative that universities integrate internationalisation as an ethos that is systematically mainstreamed in all activities, produce knowledge relevant to local and international audiences, and improve the management structure by deploying managerial capacity that corresponds to the strategic period. The article recommends that further research should be conducted on profiles of the international dimension.
\end{abstract}

Key words: internationalisation, international dimension, strategic profiles, university, Uganda

Ce article se fonde sur une étude qui a exploré la nature de et les variations dans les profils stratégiques d'internationalisation dans les universités en Ouganda. Six universités, composées de trois publiques et trois privées agréées, avec des histoires et des philosophies différentes, ont été sélectionnées pour l'étude. Les profils de rayonnement international ont été vérifiées avec un examen et une analyse des plans stratégiques et des rap-

ABOUT THE AUTHORS: RONALD BISASO AND FLORENCE NAKAMANYA East African School of Higher Education Studies and Development, Makerere University. Email: rbisaso@cees.mak.ac.ug, floranakamanya@cees.mak.ac.ug 
ports nationaux et institutionnels. Les résultats mettent en valeur six profils d'internationalisation, à savoir: vision et mission, valeurs fondamentales / partagées, taux d'inscription, échange d'étudiant.es et de professeurs, partenariats et collaborations, et structure managériale. Cet article recommande qu'une recherche plus approfondie soit menée sur les profils de rayonnement international.

Mots clés: internationalisation, rayonnement international, profils stratégiques, université, Ouganda

\section{Introduction and Context}

It is generally accepted that internationalisation is essential for building competitive and globally responsive higher education (HE) systems and institutions. While the international dimension of HE predates the inception of pre-modern HE in Africa, the rise of the global knowledge society in the early 2000 s led to increased focus on the internationalisation of HE (World Bank, 2002; Assié-Lumumba 20I7; de Wit and Altbach, 2018; Mamdani, 20I8). Furthermore, internationalisation of HE has coincided with the articulation of its political, economic, socio-cultural, and academic rationales by governments, institutions and international agencies (de Wit and Hunter, 20I8). The increased intentional interest in this phenomenon has implications for institutional strategies (Jowi, 2009). The internationalisation agenda and its entrenchment in institutional strategic plans and university activities has gained traction in the past decade (Sehoole and Jowi, 20I8). The current mission statements in the strategic plans of flagship universities in Africa highlight excellence, relevance and global competitiveness as pillars (Teferra, 20I6) in their strategic profiling.

Strategic profiles are representations of "what the institution does, how good it is at it and how it compares to other institutions" (van Vught and Huisman, 2013 p. 27). Such profiles may denote an institution's 'foci', 'core' or 'priority' areas as expressed in strategic documents. Strategic profiling of an institution can occur through the dimensions of its mission, including teaching and learning, research, and community engagement. International orientation could also be an important dimension (van Vught and Huisman, 20I3). Research on strategic profiling has focused on the responsiveness of different types of HE institutions and their agency to (re)build human resources to cope with change, entrench niches such as 'research excellence', and build diversified HE systems (Fumasoli and Huisman, 20I3; Vuori, 20I5; Vuori, 20I6; Morphew, Fumasoli and Stensaker, 20I8). Recent findings highlight that structures and identities are central to strategic profiling in universities (Fumasoli, Barbato, and Turri, 20I9). The activities that an institution chooses to engage in such as inter- nationalisation, evolve into its position, which contributes to a diversified HE system (Barbato, and Turri, 2020).

Even with strategic profiles, there is a need to improve alignment of African flagship universities' internationalisation activities with their missions and visions as they contribute to national and regional development (Andoh and Salmi, 20I9 p. 23). While the international dimension has been understood in many ways, Knight (2003) offers an updated working definition: the process of integrating an international, intercultural, or global dimension into the purpose, functions or delivery of postsecondary education (p. 2). Knight (2008) acknowledges that, whereas this definition is 'neutral', internationalisation may be seen in light of generally "improving the quality and relevance of higher education" (p. I5). However, it is not uncommon for internationalisation to be equated to the number of foreign students enrolled, the number of agreements or memoranda of understanding signed or even international accreditation or certification (Knight, 20II). These are necessary but inadequate parameters to disambiguate the international dimension in universities. Recent discourse shows that internationalisation can be understood differently in different contexts and may be regarded as "a means to enhance the quality of teaching, research and the service role of higher education to society" (de Wit and Hunter 2018 p. 4).

Strategic decisions to embed internationalisation in the core functions of $\mathrm{HE}$ are increasingly evident. While internationalisation of the content, learning outcomes, teaching and teaching methods, and assessment varies across contexts, it should take cognizance of the entire value chain. Indeed, as Leask (20I8 p. 8) argues, the curriculum ought to be "...more inclusive and less elitist than it has been in the past"; hence the need to rethink its design and implementation. This could be based on a reading of previous cross-country studies, and would benefit from visiting professors from partner institutions, hiring international faculty, the use of benchmark cases for teaching and the use of blended or online learning resources with collaborating universities.

As one of the key functions of universities, research has not been convincingly explored in the literature with respect to the international dimension. There are few studies on academic staff mobility, graduate training and research, and co-authorship of publications in the framework of internationalisation (de Wit, 20I8). Several components make up a strategy on the internationalisation of research, including a clear institutional policy; related support systems and mechanisms; international dissemination of research; development and support of international research networks and partnerships; a policy on the appointment of international scholars and doctoral students; short-term mobility opportunities for scholars and doc- 
toral students; and international teaching and learning at graduate level. Long-term investment in research capacity building, sustainable research infrastructure and the creation of functional research management structures can be integrated into strategies across universities with different profiles. There is a critical need for institutions in the Global South to develop and implement a strategy for the internationalisation of research in order to develop their capacity to collaboratively and sustainably confront global challenges such as COVID-I9, climate change, etc.

With a few exceptions, the literature has also not focused on internationalisation of the 'third mission' or the service function (Sehoole and de Wit, 20I4). Andoh and Salmi (20I9) assert that this 'third mission' is critical in the internationalisation agendas of universities in Africa if HE is to assist in addressing socio-economic asymmetries. This is consistent with the view that the internationalisation of HE in Africa should be based on continental contextual realities rather than replicating models in the developed world (Sehoole and de Wit, 20I4). Moreover, it is argued that (research-oriented) universities in developing contexts can contribute to the development of a knowledge society (Altbach, 20I3). However, this requires that, "African scholars...produce knowledge that is relevant to their own development context and ...explore avenues by which to disseminate this knowledge to students and scholars worldwide" (Sehoole and de Wit, 20I4 p. 235). African HE should thus first 'de-internationalise' or rethink current internationalisation efforts in order to rebuild relevant and internationalised institutions. Recent studies show that HE institutions are indeed strategically repositioning themselves in sync with national development priorities (Ndibuuza and Langa, 20I9).

Embedding strategic thinking in the international dimension in universities calls for strong leadership capacities. In response to global pressures, universities have opted for "the creation of new leadership roles with responsibility for developing, coordinating, and implementing an international strategy. [The new strategy is sometimes focused on] a need for senior university staff to develop new skills and awareness to support various aspects of international exchange" (Middlehurst, 2018 p. 4). In the first stage, promotion and entrenchment of the international dimension in universities has been largely the work of operational managers like the Head, International Relations Office. During the second stage, such responsibilites shifted to middle managers, e.g., Director of International Development /Director of the International Office, and in the third stage, to strategic/senior managers at the level of Deputy Vice-Chancellor in charge of International Relations (Soliman, Anchor and Taylor, 2019). In Africa, international relations offices were established at flagship universities like the University of Ghana, University of Dar es Salaam, University of
Ibadan, University of Nairobi and Makerere University in the early 2000 s (Andoh and Salmi, 20I9; Bisaso, 20I7). The titles and roles of these officers continue to be rebranded at these institutions with the possibility of transitioning through the three stages.

There is a paucity of research on internationalisation from a strategic perspective in universities (Soliman, Anchor and Taylor, 20I9). In Africa, universities' strategies, visions and missions should be the basis for the development of the international dimension in all academic processes and structures rather than mimicking and adapting emergent global trends (Andoh and Salmi, 20I9). Given the numerous demands made of them, most African HE institutions do not have internationalisation strategies. However, there are 'mentions' of internationalisation in mission and vision statements in strategic plans (Tamrat and Teferra, 20I8). The situation is further compounded by limited scholarship on the internationalisation of HE research in Africa (Bisaso and Nakamanya, 20I8). Moving beyond this, there is a need to take stock of what has transpired over the past two decades to inform the process of developing an internationalisation strategy (Andoh and Salmi, 20I9).

In Uganda, research on internationalisation of $\mathrm{HE}$ has entailed case studies on strategies for internationalisation at home by academic staff (Nakitto, 20I8) and inculcating global citizenship among graduate students through internationalisation (Ayebare, 20I9). Other studies have highlighted long-term research cooperation with agencies such as the Carnegie Corporation of New York (CCNY), the Swedish Development Agency (Sida), and the Norwegian Agency for International Development (NORAD) (Bisaso, 20I7). This article focuses on the nature of and variation in strategic profiles of internationalisation in Uganda at a time when the expanding HE system and institutions envisage embedding internationalisation in the visions, missions and the core functions of teaching, research and community engagement. It contributes to the literature on this phenomenon by exploring strategic profiling of internationalisation in universities in Uganda during the period 2010 to 2020. The specific question is: What is the nature of and variation in strategic profiles of the international dimension in universities in Uganda? The following sections present the conceptual framework employed, the method, results, and a discussion and conclusions.

\section{Evolutionary Levels of Internationalisation at Institutional Level}

The study employed a framework on universities' internationalisation trajectories. As illustrated in Figure I, an internationalisation strategy can be either deliberate or emergent, defined by temporal variation. A deliberate strategy covers a specific strategic period whereas an emergent strategy is 
made up of several strategic periods. First, internationalisation in universities is manifested in disjointed activities that are often 'not mentioned' in the previous strategic plan. Second, internationalisation activities increase in number and are 'mentioned' in the strategic plan. Third, internationalisation becomes a core strategic priority in the university and an internationalisation strategy is developed. With respect to structure, in the first stage, internationalisation activities are popularised by operational managers such as the Head of the International Office. In the second stage, the international dimension is entrenched by middle managers, e.g., Director of International Development while in the third stage, senior managers, e.g., Pro-Vice Chancellor (International) manage the internationalisation agenda in the university. The nature of and variations in strategic profiling in this article are informed by the framework's focus on the evolutionary levels of internationalisation in line with the successive nature of the strategic plans analysed.

Figure 1. Phases of International Strategies in Universities

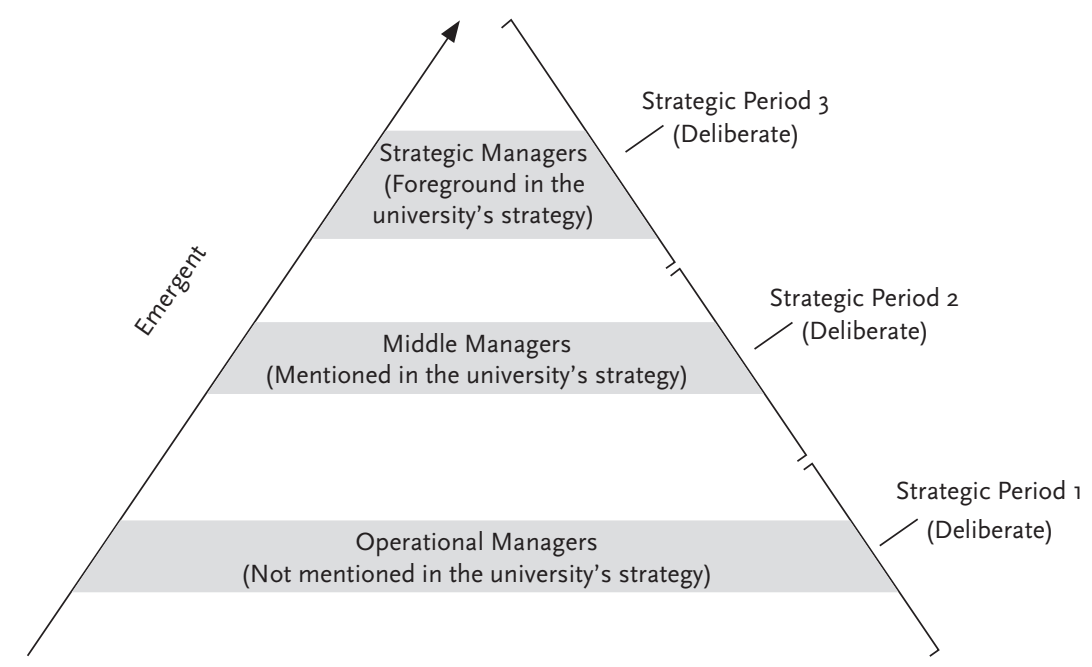

Adapted from Soliman, Anchor and Taylor, 2019

\section{Method}

The study adopted a multiple case study design as the focus was to contribute to the development of internationalisation strategies in universities with different profiles. This entailed understanding the complexity of the context to inform appropriate action (Cohen, Manion, and Morrison,
2007). Six universities (three public and three private) were selected from the nine chartered private universities and nine public universities in existence in 20I9. The public institutions included Makerere University, a public 'flagship' university established in I922 and located in the capital city, Mbarara University of Science and Technology (MUST), the second oldest university established in a peripheral region in I989, and Busitema University, a third generation multi-campus merged university that commenced operations in 2007 . The three private universities were chartered by the Government of Uganda and included Uganda Christian University (UCU), a religiously-affiliated university chartered in 2004, Nkumba University categorised as a private-for-profit university chartered in 2007 , and Mountains of the Moon University (MMU), a community-oriented university chartered in 2017 .

Data was gathered by means of document review and analysis, which provided authentic data over a period of time (Bowen, 2009). Relevant data was extracted from the documents after coding and the codes were coalesced into categories that were later merged to generate themes. The review and analysis of documents was informed by Scott's (I990) quality criteria for document data including authenticity, credibility, representativeness and meaning. To understand both the internal and external institutional environments, important documents such as the Education and Sports Sector Strategic Plan of the Ministry of Education and Sports, the National Council for Higher Education's (NCHE) State of Higher Education reports, and current or immediate past university strategic plans were reviewed. Additional data was sought from the universities' official websites which provided a strategic perspective on internationalisation of HE. The documents employed were either developed and/or implemented during the period 2010-2020. The key profiles of the international dimension that emerged from the analysis included the vision and mission profile, the shared/core value profile, student enrolment profile, the staff and student exchange profile, the partnerships/collaborations profile, and the management structure profile.

\section{Results}

The study's results reveal a range of and variations in the universities' strategic profiles. The internationalisation profiles are based on the extent to which they recurred across the universities.

Vision and Mission Profile

While there is no clear strategy at the HE system level in Uganda, the Education and Sports Sector Strategic Plan 20I7/I8-20I9/2020 'mentions' the importance of international education agendas, namely the UN Sustain- 
able Development Goals (SDGs), specifically SDG 4 on ensuring inclusive and quality education for all and promoting lifelong learning and its 2030 targets (Ministry of Education and Sports, 20I7, pp. 5-7).

One of the ways to strategically profile the international dimension in universities in Uganda is to analyse the vision and mission statements. As illustrated in Table I, the vision and mission statements of universities vary with respect to the focus on the international dimension. Two public universities - the oldest and second oldest - 'mention' internationalisation in their mission statements:

To provide innovative teaching, learning, research and services responsive to National and Global needs (Makerere University)

To provide quality and relevant education at national and international levels with particular emphasis on science and technology and its application to community development (Mbarara University of Science and Technology).

Conversely, the vision statements of two of the private universities UCU, a religiously-affiliated institution, and Nkumba University, which in this study was classified as private-for-profit, and the oldest public university, Makerere University express a continental or global orientation in their strategic aspirations.

A Centre of Excellence in the Heart of Africa (Uganda Christian University)

To be a leading national, regional and global hub for academic and professional excellence (Nkumba University)

To be the leading institution for academic excellence and innovations in Africa (Makerere University)

Such 'mentions' of internationalisation in strategy documents indicate awareness of this phenomenon in universities although it is not necessarily operationalised in the strategic objectives. Consistent with the framework presented in Figure I, the mission statements are the deliberate strategy, while the vision statements are the emergent strategy that becomes evident after successive deliberate strategies. It is important to note that the strategies of all six universities are successor strategies and hence could be situated in strategic period 2.
Table 1. Vision and Mission Statements of Universities in Uganda

\begin{tabular}{|c|c|c|c|c|}
\hline SN & Status & Year & University & Strategic Statements \\
\hline \multirow[t]{3}{*}{1.} & \multirow[t]{3}{*}{ Public } & 1922 & $\begin{array}{l}\text { Makerere } \\
\text { University }\end{array}$ & $\begin{array}{l}\text { Vision: To be the leading institution for academic } \\
\text { excellence and innovations in Africa } \\
\text { Mission: To provide innovative teaching, learning, } \\
\text { research and services responsive to National and } \\
\text { Global needs }\end{array}$ \\
\hline & & 1989 & $\begin{array}{l}\text { Mbarara } \\
\text { University of } \\
\text { Science and } \\
\text { Technology }\end{array}$ & $\begin{array}{l}\text { Vision: To be a Centre for academic and } \\
\text { professional excellence in science and technology. } \\
\text { Mission: To provide quality and relevant education } \\
\text { at national and international levels with particular } \\
\text { emphasis on science and technology and its } \\
\text { application to community development. }\end{array}$ \\
\hline & & 2007 & $\begin{array}{l}\text { Busitema } \\
\text { University }\end{array}$ & $\begin{array}{l}\text { Vision: A centre of academic and professional } \\
\text { excellence in science, technology and innovation } \\
\text { Mission: To provide high standard training, engage } \\
\text { in quality research and outreach for socioeconomic } \\
\text { transformation and sustainable development. }\end{array}$ \\
\hline \multirow[t]{3}{*}{2.} & \multirow[t]{3}{*}{$\begin{array}{l}\text { Private } \\
\text { Chartered }\end{array}$} & 2004 & $\begin{array}{l}\text { Uganda } \\
\text { Christian } \\
\text { University }\end{array}$ & $\begin{array}{l}\text { Vision: A Centre of Excellence in the Heart of Africa } \\
\text { Mission: To Equip students for productive, holistic } \\
\text { lives of Christian faith and service. (This was } \\
\text { adapted from Uganda Christian University, 2020a) }\end{array}$ \\
\hline & & 2007 & $\begin{array}{l}\text { Nkumba } \\
\text { University }\end{array}$ & $\begin{array}{l}\text { Vision: To be a leading national, regional and global } \\
\text { hub for academic and professional excellence } \\
\text { Mission: To provide quality education that } \\
\text { cultivates competence, confidence, creativity and } \\
\text { high moral character in teaching and learning, } \\
\text { research and community engagement }\end{array}$ \\
\hline & & 2017 & $\begin{array}{l}\text { Mountains } \\
\text { of the Moon } \\
\text { University }\end{array}$ & $\begin{array}{l}\text { Vision: To be a centre of excellence in teaching, } \\
\text { research and community engagement. } \\
\text { Mission: To produce outstanding, well rounded, } \\
\text { morally up right and innovative graduates with a } \\
\text { knowledge base for making positive impacts on the } \\
\text { community }\end{array}$ \\
\hline
\end{tabular}

Shared/Core Value Profile

The universities profiled internationalisation as a core value, shared value or a cross-cutting issue. This is perhaps an indicator that they are building a culture of internationalisation in all institutional processes. It was evident in all three public universities in the study. Makerere University regarded internationalisation as a cross-cutting issue to be manifested in the number of foreign students, integration of internationalisation in teaching, learning and collaborative research, joint degree awards, franchising programmes 
in foreign countries, and the establishment of branch campuses in other countries. Along similar lines, MUST considered internationalisation as one of the institution's shared values. The expected action in this regard was that, the university would grow partnerships with leading institutions across the world (Mbarara University of Science and Technology, 2016 p. IO). In the same vein, Busitema University (20I7) highlights internationalisation as one of the university's values. This value is anchored on "participating in the regional and global world of scholarship by being receptive and responsive to issues pertinent to the international community" (Busitema University, 20I7, p. 4). All this points to institutional efforts to build a culture of internationalisation and its practice in all institutional functions.

\section{Student Enrolment Profile}

Enrolment of international students is another emergent profile. A review of the State of Higher Education reports and other documents shows that the number of international students in the Ugandan HE system has been minimal. For instance, in $2014 / 2015$, there were only 20,892 international students among total enrolment of 257,855 , constituting $8 \%$ of the student body. The highest concentration was in the field of theology and most of the students were from the Democratic Republic of Congo (DRC), South Sudan, Somalia, Kenya, Nigeria, and some from the US, mainly on exchange programmes (Achanga and Bisaso, 20I8). In 20I8, the NCHE highlighted a drop in the number of international students from 18,943 in $2015 / 2016$ to I 8,478 in $2016 / 2017$. The highest percentage of international students enrolled $(85.39 \%)$ was in universities, other tertiary institutions specialising in business and commerce $(5.48 \%)$, social development and management (3.69\%), Other Degree Awarding Institutions (2.60\%), and theology (I.60\%), with the remainder comprising I.24\% (NCHE, 2018 pp. 3I-32). Overall, the statistics accessed by the authors show a consistent decline in enrolment of international students in the Ugandan HE system. While all the country's HE institutions are required to disaggregate data on international students enrolled in their institutions by nationality, the NCHE report revealed that most did not provide data on international students.

Data from universities that do provide such information such as Makerere University points to low and declining enrolment of international students during the period 2008/09 to 20I8/20I9. For instance, whereas in 2008 international students comprised $8 \%$ of the total student population, by 2015 , the number had declined to only $2 \%$ (Makerere University, 20I7a, p. 69). However, private universities have strategically and practically highlighted attracting international students as a way of internationally profiling the institution. For instance, UCU (private religiously-affiliated) aims to "ensure that information and applications are available nationally and internationally in all media" as well as "encourage recruitment and enrolment of international students..." (UCU, 20I2 pp. 22-23). Though not stated as a market-oriented strategy, UCU has international students' liaison centres or international recruitment centres in four East African countries, namely, Kenya, Tanzania, Rwanda and Burundi. On the other hand, Nkumba University (categorised as private for profit), intends to increase its intake of foreign students in order to realise the University's strategic priority of "diversifying sources of funds and strengthening financial management" (Nkumba University, 20I4, p. 25). A similar focus on international student recruitment is evident in MMU (private community university) under the strategic issue, 'marketing and partnerships', which will be realised through an "increase in number of international students... [comprising] 5 per cent from international locations by 2013 " (MMU, 20II, p. 56).

\section{Staff and Student Exchange Profile}

Universities also note staff and student exchange arrangements as a profile for the international dimension. Consistent with its vision of being a "global hub for academic and professional excellence", Nkumba University (private-for-profit university) expects to strengthen its teaching and learning function through involvement in staff exchanges and ensuring that all university curricula are regionally and internationally comparable (Nkumba University, 2014 p. 20). Along similar lines, UCU anticipated improvement in teaching and learning through networking with other universities to improve its courses so that they are acceptable for credit transfer and becoming involved in graduate student exchange arrangements with recognised universities (UCU, 20I2, p. I6). Makerere University envisaged the provision of flexible teaching and learning programmes that meet national and international standards by the end of 2013 (Makerere University, 2008 p. I5). Consistent with this, the strategic review report points to a range of international activities already implemented including staff and student exchange programmes, summer schools and joint degrees with other universities (Makerere University, 20I7b).

Partnerships and Collaborations Profile

Universities consider internationalisation of research as a strategic priority irrespective of institutional type. This profile shows prioritisation of partnerships and collaborations which are enacted through memoranda of understanding (MoUs). Makerere University highlighted research and innovation as a pillar in its strategic focus. To actualise this, the univer- 
sity had signed 303 MoUs in the period 2008 to 20I4, spanning three to five years, with only a few lasting ten years. A range of partnerships have been sustained that were implemented through activities such as research capacity development, joint research and transfer of research materials (Makerere University, 2oI7b).

Mbarara University of Science and Technology articulates internationalisation of research in the form of building research partnerships, with a target of a 1०\% increase in national and international partnerships by 2018 . MUST reports on a partnership initiated in 2015 with the National Institutes of Health (NIH) as a public university in a peripheral region that focuses on medical and health sciences among other fields (MUST, 20I6, p. 7). At the newer third generation merged public university, internationalisation of research is expected to be achieved by fostering collaborative partnerships in research and innovation through collaboration with research institutions and development partners. Busitema University's partnerships were to be ratified by at least six MoUs during the period 2018 to 2020 (Busitema University, 20I7 pp. I0; 26).

Private universities also profile internationalisation of research as a strategic priority. UCU focused on increasing strategic partnerships for research and programme development as well as offering support for the development of "centres of excellence" for research. This would entail identifying partners and signing MoUs with them (UCU, $2012 \mathrm{pp}$. I8-I9). Similarly, Nkumba University is to broadly strengthen research and publishing through initiating collaboration and aligning research to regional priorities (Nkumba University, 20I4). Meanwhile, MMU envisaged developing strong research partnerships with regional, national and international organisations (MMU, 20II p. 26). Overall, partnerships and accompanying MoUs are the profile for the internationalisation of research at strategic level in universities in Uganda.

\section{Management Structure Profile}

Management structures for integrating internationalisation into university activities are critical. As a profile, the existing structures for the international dimension focus mainly on students' support services. For example, at Makerere University, the International Relations Office (IRO) established in 2004 is headed by the International Relations Officer/Senior Administrative Assistant and falls under the Office of the Vice-Chancellor. It is mandated to spearhead all internationalisation processes and activities in the university but its focus has been limited to international student support even in the strategic period 2008/2009-2018/2019 (as amended) (Makerere University, 2008). At UCU, there is a Directorate of Student Affairs (DOSA) led by a Director assisted by an International Students'
Administrator (UCU, 2020b). Other universities have only expressed intentions to develop and sustain such structures. For example, MUST was set to develop and maintain an International Students Office/Information Office and establish a Corporate and International Office to support the institution's outreach and engagement programmes (MUST, 20I6). In the same vein, Nkumba University was planning to set up an International Students' Office in order to enhance students' welfare (Nkumba University, 20I4). Clearly, both existing and prospective structures for internationalisation seem to focus on students, specifically international students.

\section{Discussion and Conclusion}

Historically, HE in Africa has been internationalised as a replica of the systems in the colonising countries. The international dimension in universities in Uganda has been strategically profiled in a range of ways sometimes informed by institutional philosophies and histories. Based on the 'mentions' in their vision and mission statements, strategic objectives and actions/strategies, the country's universities have been embracing internationalisation. The analysis of these 'mentions' shows that the university strategies are probably in the second strategic period illustrated in Figure I (Soliman, Anchor and Taylor, 20I9). A novel issue that emerges from the findings is that, internationalisation is one of the shared/core values or cross-cutting issues in the three public universities. This illuminates efforts to 'integrate' the international dimension "into the purpose, functions or delivery of postsecondary education" (Knight, 2003, p. 2; 2008; 20II). Of course, such integration is still ambiguous and staggered in the different profiles; hence the need for more systematised attention to mechanisms to internationalise the core functions of teaching, research and community engagement.

The international dimension has also been profiled as student enrolment. While there is a general decline in enrolment of international students at both the Ugandan HE system and institutional levels (Achanga and Bisaso, 20I8; NCHE, 20I8; Makerere University, 20I7a), the universities profile this as perhaps one of the most critical indicators of the international dimension. Most set out strategies to attract international students through aggressive advertising, marketing, and through established recruitment centres. It should be noted that, whereas this is an important profile of the international dimension, universities ought to explore alternative, innovative ways to entrench it, including blended or online teaching and learning (Leask, 20I8).

Staff and student exchanges is another of the profiles for the international dimension in universities in Uganda. This buttresses aspirations for improved teaching and learning that ensures that all academic programmes 
are internationally comparable and of acceptable quality for engagement in credit transfer arrangements with universities in different parts of the world. This profile is consistent with Leask's call to redesign and implement curricula that are ".... more inclusive and less elitist than ... in the past" (Leask, 20I8, p. 8). Universities could also encourage innovation in teaching by using benchmarked cases and recruitment of visiting professors.

Universities have profiled internationalisation of research by embracing partnerships and collaborations in varying degrees. These are enacted through MoUs that span three to five and sometimes ten years to entrench research capacity building. There is evidence that some of the younger universities are curving out niches in community-oriented research as well as indigenous knowledge systems and sustainable development. Such efforts would be ratified through meeting the targets set out in signed MoUs. Other universities have earmarked support for creating "centres of excellence" and building strategic partnerships with national, regional and international agencies. While these are all necessary strategies, it is important that universities set achievable targets that match international aspirations with institutional niches and capacities. Furthermore, issues such as a clear institutional policy, international dissemination of research, short-term mobility opportunities for scholars and international teaching and learning at graduate level (de Wit, 20I8) ought to be considered, mainstreamed and strengthened.

Finally, the study established that with the exception of Makerere University and UCU, which have managers responsible for internationalisation, the rest of the universities were planning to establish such offices or desks. It is important to note that even where managers were in place, the focus was mainly on direction and coordination of international student affairs. Furthermore, whereas universities are presumably at 'strategic period 2' where internationalisation is 'mentioned' in their strategies, visions and missions as illustrated in Figure I, corresponding management of the internationalisation office is still at operational level, namely, Head, International Relations Office or Director of Student Affairs which is in 'strategic period I'. This mismatched management capacity explains the focus on executing only the international student enrolment profile among other profiles. The management structure profile should have been at middle management level - Director of International Development - which aligns with 'strategic period 2' (Soliman, Anchor and Taylor, 2019). This mismatch possibly accounts for the nature of and variations in the profiles of the international dimension in this study. It is imperative that, as universities aspire to move to 'strategic period 3', as shown in Figure I, managers of the international dimension should have corresponding capacity or should be appropriately capacitated to systematically integrate internationalisation "into the purpose, function or delivery of postsecondary education" (Knight, 2003, p. 2). Overall, we argue that all the profiles of the international dimension in universities in Uganda highlighted in this article should be harnessed and studied further.

\section{References}

Achanga P.C., and Bisaso R. (2018). Higher Education Systems and Institutions: Uganda. In: J. C. Shin, and P. Teixeira (eds.) Encyclopedia of International Higher Education Systems and Institutions. https://doi. org/I0.I007/978-94-0I7-9553-I_477-I. Dordrecht: Springer.

Altbach, P.G. (20I3). Advancing the national and global knowledge economy: the role of research universities in developing countries. Studies in Higher Education 38(3), 316-330.

Andoh, H., and Salmi, J. (2019). The internationalization agenda of African universities in the next decade. International Higher Education 99 (Fall), 2I-23

Assié-Lumumba, N.T. (20I7). African University Traditions, Historical Perspective. In: J.C. Shin and P. Teixeira (eds.) Encyclopedia of International Higher Education Systems and Institutions. https://doi. org/10.I007/978-94-0I7-9553-I_IO-I Dordrecht: Springer.

Ayebare, J. (2019). Internationalisation of Higher Education and the Global Citizenship of Graduate Students at Makerere University. Unpublished PhD dissertation, Makerere University.

Barbato, G., and Turri, M. (2020). What do positioning paths of universities tell about the diversity of higher education systems? An exploratory study. Studies in Higher Education 45(9), I919-I932.

Bisaso, R., and Nakamanya, F. (2018). Internationalization of higher education research and careers in Africa. In: J. C. Shin, and P. Teixeira (eds.) Encyclopedia of International Higher Education Systems and Institutions. https://doi.org/IO.I007/978-94-OI7-9553-I_2II-I. Dordrecht: Springer.

Bisaso, R. (20I7). Makerere University as a flagship institution: sustaining the quest for relevance. In: D. Teferra (ed.) Flagship universities in Africa, pp. 425-466. New York: Palgrave MacMillan.

Bowen, G.A. (2009). Document analysis as a qualitative research method. Qualitative Research Journal 9(2), 27-40.

Busitema University. (2017). Strategic Plan. 2018/19-2019/20. Busitema: Author.

Cohen, L., Manion, L., and Morrison, K. (2007). Research methods in education. London: Routledge Taylor and Francis Group.

de Wit, H. (20I8). Internationalization of research and knowledge development. In: J. C. Shin, and P. Teixeira (eds.) Encyclopedia of International Higher Education Systems and Institutions. https://doi.org/Io.1007/97894-0I7-9553-I_257-I Dordrecht: Springer. 
de Wit, H., and Altbach, P.G. (20I8). Higher Education as global reality. In: J. C. Shin, and P. Teixeira (eds.) Encyclopedia of International Higher Education Systems and Institutions. https://doi.org/10.1007/978-94OI7-9553-I_2I3-I

de Wit, H., and Hunter, F. (20I8). Internationalization of higher education: evolving concepts, approaches, and definitions. In: J. C. Shin, and P. Teixeira (eds.) Encyclopedia of International Higher Education Systems and Institutions. https://doi.org/I0.I007/978-94-0I7-9553-I_567-I Dordrecht: Springer.

Eisemon, T. O., and Salmi, J. (I993). African universities and the state: Prospects for reform in Senegal and Uganda. Higher Education 25(2), I5I-I68.

Fumasoli, T., and Huisman, J. (2013). Strategic agency and system diversity: conceptualizing institutional positioning in higher education. Minerva 52(2), I55-I69.

Fumasoli, T., Barbato, G., and Turri, M. (20I9). The determinants of university strategic positioning: a reappraisal of the organization. Higher Education 80, 305-334.

Jowi, J. O. (2009). Internationalization of Higher Education in Africa: Developments, Emerging Trends, Issues and Policy Implications. Higher Education Policy 22(3), 263-28I.

Knight, J. (2003). Updated internationalization definition. International Higher Education 33, 2-3.

Knight, J. (2008). The Internationalization of Higher Education: Complexities and Realities. In: D. Teferra and J. Knight (eds.) Higher Education in Africa: The International Dimension, pp. I-43. Boston/Accra: Center for International Higher Education/ Association of African Universities.

Knight, J. (20II). Five myths about internationalization. International Higher Education 62 (Winter), I4-I5.

Leask, B. (2018). Internationalization of the curriculum, teaching and learning. In: J. C. Shin, and P. Teixeira (eds.) Encyclopedia of International Higher Education Systems and Institutions. https://oi. org/IO.I007/978-94-0I7-9553-I_244-I Dordrecht: Springer.

Makerere University. (2008). Makerere University Strategic Plan. 2008/092018/19. Kampala: Author.

Makerere University. (20I7a). Makerere University Self-Assessment Report 2017. Kampala: Makerere University Directorate of Quality Assurance.

Makerere University. (20I7b). Makerere University Strategic Plan Review Report - February 2017. Kampala: Makerere University Planning and Development Department.

Mamdani, M. (20I8). The African university. London Review of Books 40(I4), $29-32$.
Mbarara University of Science and Technology. (2016). Strategic Plan. 2017/18-2019/2020. Mbarara: Author.

Middlehurst, R. (20I8). Leadership of internationalization in higher education institutions. In: J. C. Shin, and P. Teixeira (eds.) Encyclopedia of International Higher Education Systems and Institutions. https://doi. org/IO.I007/978-94-0I7-9553-I_539-I Dordrecht: Springer.

Ministry of Education and Sports. (20I7). Education and Sports Sector Strategic Plan 2017/18-2019/2020. Kampala: Author.

Morphew, C.C., Fumasoli, T., and Stensaker, B. (2018). Changing missions? How the strategic plans of research-intensive universities in Northern Europe and North America balance competing identities. Studies in Higher Education 43(6), I074-1088.

Mountains of the Moon University. (20II). Ten Year Strategic Plan 2011-2021. Fort Portal: Author.

Nakitto, Z. (20I8). Strategies for Internationalization at Home by Academic Staff in the College of Education and External Studies, Makerere University. Unpublished Masters dissertation, Makerere University.

National Council for Higher Education. (2018). The State of Higher Education and Training in Uganda 2016/17. A Report on Higher Education Delivery and Institutions. Kampala: Author.

Ndibuuza, F., and Langa, P. (2019). The tale of academic practice in a rising knowledge society: focus on a university in South Africa. Tertiary Education and Management. https://doi.org/I0.I007/sII233-0I9-09036-X

Nkumba University. (2014). Nkumba University Strategic Plan 2013/142023/2024. Nkumba: Author.

Scott, J. (I990). A Matter of Record: Documentary Sources in Social Research. Cambridge: Polity Press.

Sehoole, C., and De Wit, H. (20I4). Regionalization, Internationalization and Globalization of African Higher Education. International Journal of African Higher Education 1(I), 2I8-24I.

Sehoole, C., and Jowi, J. (20I8). Internationalization of Higher Education, Africa. In: J. C. Shin and P. Teixeira (eds.), Encyclopedia of International Higher Education Systems and Institutions. https://oi. org/I0.1007/978-94-0I7-9553-I_230-I

Soliman, S., Anchor, J., and Taylor, D. (2019). The international strategies of universities: deliberate or emergent? Studies in Higher Education 44(8), I4I3-I424.

Tamrat, W., and Teferra, D. (20I8). Internationalization of Ethiopian higher education institutions: manifestations of a nascent system. Journal of Studies in International Education 22(3), 434-453.

Teferra, D. (20I6). African flagship universities: their neglected contributions. Higher Education 72, 79-99. 
Teferra, D. (20I7). African Flagship Universities in the Era of "Massification". In: D. Teferra (ed.) Flagship universities in Africa, pp.I-I6. New York: Palgrave MacMillan.

Uganda Christian University. (2012) Strategic Plan 2012-2018. Abridged version. Approved by University Council 24 May 2012. Mukono: Author.

Uganda Christian University. (2020a). Uganda Christian University's Vision, Mission and Values. https://ucu.ac.ug/about/facts/our-values Retrieved Io July, 2020.

Uganda Christian University. (2020b). Uganda Christian University's Vision, Mission and Values. https://ucu.ac.ug/international-applicants Retrieved io July, 2020.

van Vught, F., and Huisman, J. (2013). Institutional profiles: some strategic tools. Tuning Journal for Higher Education 1(I), 2I-36.

Vuori, J. (20I5). Making sense of institutional positioning in Finnish higher education. Tertiary Education and Management 21(4), 316-327.

Vuori, J. (2016). Towards strategic actorhood? The execution of institutional positioning strategies at Finnish Universities of Applied Sciences. Higher Education Quarterly 70(4), 400-4I8.

World Bank. (2002). Constructing Knowledge Societies: New Challenges for Tertiary Education (Chapter I: The Changing Global Environment pp. 7-22). Washington DC: The World Bank. 